\title{
FREQUENCY OF ANXIETY AND ITS RISK FACTORS AMONG WORKING \& NON WORKING WOMEN OF PESHAWAR
}

\author{
Nighat Musa ${ }^{1}$, Yasir Mehmood ${ }^{1}$, Sofia Kabir ${ }^{2}$, Asghar Khan ${ }^{3}$ \\ 1. Kabir Medical College, Peshawar \\ 2. Sardar Begum Dental College, Peshawar \\ 3. Technical Support Officer, CDC
}

ABSTRACT

OBJECTNE: to determine the frequency of anxiety \& its risk factors among working and nonworking women.

METHODOLOGY: Study design was descriptive observational. The study duration was seven months (June-December 2016). It was a community based study.

Sample size for this study was calculated on 52\% prevalence of anxiety Pakistan. A total of 400 women were selected (200 working and 200 non-working women). A semi structured questionnaire was used along with Taylor manifest anxiety scale as study tool. Data was presented in the form of tables and graphs.

\section{RESULTS:}

The frequency of anxiety was $58 \%$. Anxiety was more among working women than non-working women. Most of the women were literate $65.5 \%$. Majority of the women having anxiety were living in nuclear family. The age group most effected was between 21-35 years (67\%), 58\% were married, single were $34 \%$ and $8 \%$ were either divorced or widow. Approximately $58 \%$ of women with anxiety had less than 2 children and 42\% were having more than 2 children. Approximately $88 \%$ women with anxiety belonged from low and middle income group having less than 20,000/-PKR and 20,001$50,000 /-P K R$ household income respectively. Only 12\% belonged from high group having more than 50,001/- PKR.

Conclusions: Anxiety is more common among working women. Married women living in nuclear family system, being single, young age group between 21-35 years, less than 2 children and low household income were the key risk factors.

KEY WORDS: anxiety, risk factors, women, illiteracy

\section{INTRODUCTION:}

Anxiety is a state of psychological arousal that results when external demands exceed person's capabilities. Generally, it has been observed that women are more at risk of getting stress as compare to men. The most likely reason of having stress among working women could be because of the dual demanding role of women at workplace and at home. Many sociologists had described

Correspondence:

Dr. Nighat Musa

Kabir Medical College

Contact: 0345-9294158

Email: nighatmusa@yahoo.com

https://doi.org/10.37762/jgmds.4-2.16 women as struggling to achieve the male's work standard, while at the same time trying to maintain the perfect wife and mother standards at home. Anxiety is NOT unknown or uncontrollable disease or illness that one can develop or inherit. Anxiety can results from a certain style of behavior. ${ }^{1}$

Different research studies had shown that Anxiety disorders are common in the general population around the world ${ }^{2}$. The exact prevalence of anxiety and its disorders in Pakistan is not pretty clearly known. Several studies have measured the prevalence of anxiety with depression, statistics varying from $7 \%$ to $50 \%$ in different centers located in urban areas $^{3,4}$.

A study conducted in northern areas of Pakistan by Agha Khan University showed that among women anxiety was $25 \%$ and anxiety with depression was $17 \%{ }^{5}$. Another study done in Karachi showed that anxiety among females was $39.4 \%{ }^{6}$. A study done in Peshawar showed $52 \%$ anxiety among women of both working and non-working groups ${ }^{7}$. 


\section{METHODOLOGY:}

A cross sectional study was conducted among working and non-working women in Peshawar. This study was conducted over the period of seven (07) months i.e; June - December 2016. A total of 400 samples were selected based on 52\% prevalence of anxiety among Pakistani women. 200 participants were from working women and 200 were non-working women.

Subjects were selected by non-probability convenient sampling technique. Interviews were conducted by trained field data collectors.

Informed consent from the participants was taken and confidentiality was ensured.

Data collection tool was semi structured questionnaire along with the Taylor manifest anxiety scale. A pilot study was conducted on $10 \%$ of sample size after translating the scale in Urdu for better understanding of most of the subjects especially housewives. The questionnaire contained the characteristics like age, marital status, education, family system, number of children and household income. Taylor manifest anxiety scale has 50 items each having response yes or no. The higher score means more anxiety and lower score means less anxiety. The results were reflected in the form of tables with percentages.

\section{RESULTS:}

Out of 400 women (200 working and 200 non- working) studied 253 (58\%) were having anxiety. Approximately anxiety was found in $75 \%$ working and $43 \%$ non-working women (Table 1). High anxiety according to the scale was found in $37.5 \%$ working and $19 \%$ non-working women (Table 2). Out of 235 women with anxiety most of them were literate $(65.5 \%)$ having $21 \%$ matriculate, $30 \%$ graduate and $14.5 \%$ were having post graduate qualification. Only $34.5 \%$ were illiterate (Table 3 ). Statistical analysis of family system showed that $28.5 \%$ women were living with joint family system and majority of women experiencing anxiety were having nuclear family system $71.5 \%$. Independent analysis between working and non-working women showed same trend of high anxiety among nuclear families as compare to joint families (Table 4).

Majority of the women having anxiety belonged to age group $21-35$ years (67\%), 25\% were having age more than 36 years and only $8 \%$ were below 20 years of age (Table 5). Most of the women were married with $58 \%$, single were $34 \%$ and $8 \%$ were either divorced or widow. Regarding marital status further analysis of data showed that $50 \%$ of women having anxiety among working class were not married as compare to $7 \%$ of non-working women (Table 6).

Approximately $58 \%$ of women with anxiety had less than 2 children and $42 \%$ were having more than 2 children. Among working women with anxiety $65.3 \%$ of women were having less than 2 children and $34.7 \%$ had more than 2 children as compare to non-working women who had $44.7 \%$ less than 2 children and $55.3 \%$ having more than 2 children (Table 7 ). Approximately $88 \%$ women with anxiety belonged from low and middle income group having less than 20,000/-PKR and 20,001$50,000 /-P K R$ household income. Only $12 \%$ belonged from high group having more than 50,001/PKR.

TABLE 1: FREQUENCY OF ANXIETY AMONG WORKING AND NON-WORKING WOMEN

\begin{tabular}{|l|l|l|l|}
\hline \multirow{2}{*}{ Category } & Anxiety & Total \\
\cline { 2 - 3 } & $\begin{array}{l}\text { Present } \\
\mathrm{N}(\%)\end{array}$ & $\begin{array}{l}\text { Absent } \\
\mathrm{N}(\%)\end{array}$ & \\
\hline Working women & $150(75 \%)$ & $50(25 \%)$ & 200 \\
\hline Non-working women & $85(43 \%)$ & $115(57.5 \%)$ & 200 \\
\hline Total & $235(58 \%)$ & $165(42 \%)$ & 400 \\
\hline
\end{tabular}

TABLE 2: DISTRIBUTION OF SAMPLE BY TMA CATEGORIES

\begin{tabular}{|l|l|l|l|}
\hline Anxiety score & Working & Non-working & Total \\
\hline Normal (low anxiety) & $50(25 \%)$ & $115(57.5 \%)$ & 165 \\
\hline Border line & $75(37.5 \%)$ & $47(23.5 \%)$ & 122 \\
\hline Abnormal (high anxiety) & $75(37.5 \%)$ & $38(19 \%)$ & 113 \\
\hline Total & 200 & 200 & 400 \\
\hline
\end{tabular}


TABLE 3: EDUCATION OF WOMEN PRESENTED WITH ANXIETY

\begin{tabular}{|l|l|l|l|l|l|}
\hline Category & Iliterate & Matric & Graduate & Post graduate & Total \\
\hline Working & $58(38.7 \%)$ & $30(20 \%)$ & $33(22 \%)$ & $29(19.3 \%)$ & 150 \\
\hline Non-working & $23(27 \%)$ & $20(24 \%)$ & $37(44 \%)$ & $5(5.8 \%)$ & 85 \\
\hline Total & $81(34.5 \%)$ & $50(21 \%)$ & $70(30 \%)$ & $34(14.5 \%)$ & 235 \\
\hline
\end{tabular}

TABLE 4: FAMILY SYSTEM OF WOMEN PRESENTED WITH ANXIETY

\begin{tabular}{|l|l|l|l|}
\hline Category & Joint family & Nuclear family & Total \\
\hline Working & $40(27 \%)$ & $110(73 \%)$ & 150 \\
\hline Non-working & $27(32 \%)$ & $58(68 \%)$ & 85 \\
\hline Total & $67(28.5 \%)$ & $168(71.5 \%)$ & 235 \\
\hline
\end{tabular}

TABLE 5: AGE OF WOMEN HAVING ANXIETY

\begin{tabular}{|l|l|l|l|l|}
\hline Category & Less than 20 years & $21-35$ years & More than 36 years & Total \\
\hline Working & $10(6.7 \%)$ & $100(66.7 \%)$ & $40(26.6 \%)$ & 150 \\
\hline Non-working & $8(9.4 \%)$ & $58(68.2 \%)$ & $19(22.4 \%)$ & 85 \\
\hline Total & $18(8 \%)$ & $158(67 \%)$ & $59(25 \%)$ & 235 \\
\hline
\end{tabular}

TABLE 6: MARITAL STATUS OF WOMEN PRESENTED WITH ANXIETY

\begin{tabular}{|l|l|l|l|l|}
\hline Category & Single & Married & Divorced/widow & Total \\
\hline Working & $75(50 \%)$ & $60(40 \%)$ & $15(10 \%)$ & 150 \\
\hline Non-working & $6(7 \%)$ & $76(89.4 \%)$ & $3(3.6 \%)$ & 85 \\
\hline Total & $81(34 \%)$ & $136(58 \%)$ & $18(8 \%)$ & 235 \\
\hline
\end{tabular}

TABLE 7: NUMBER OF SIBLINGS OF WOMEN PRESENTED WTH ANXIETY

\begin{tabular}{|l|l|l|l|}
\hline \multirow{2}{*}{ Category } & Number of children & Total \\
\cline { 2 - 4 } & Less than 2 children & More than 2 children & \\
\hline Working & $98(65.3 \%)$ & $52(34.7 \%)$ & 150 \\
\hline Non-working & $38(44.7 \%)$ & $47(55.3 \%)$ & 85 \\
\hline Total & $136(58 \%)$ & $99(42 \%)$ & 235 \\
\hline
\end{tabular}

TABLE 8: HOUSEHOLD INCOME OF WOMEN PRESENTING WITH ANXIETY

\begin{tabular}{|l|l|l|l|l|}
\hline Category & Low income & Middle income & High income group & Total \\
\hline & Less than 20,000/month & $20,001-50,000 /$ month & More than 50,001 & \\
\hline Working & $78(52 \%)$ & $52(34.7 \%)$ & $20(13.3 \%)$ & 150 \\
\hline Non-working & $44(52 \%)$ & $33(39 \%)$ & $8(9 \%)$ & 85 \\
\hline Total & $122(52 \%)$ & $85(36 \%)$ & $28(12 \%)$ & 235 \\
\hline
\end{tabular}

\section{DISCUSSION:}

The prevalence of anxiety and depression is universal, but varies in different countries, environments, between gender and different age groups. Anxiety is studied along with depression in many studies as often the patient experience symptoms of anxiety with depression. Current study was purely done on anxiety and its associated factors among women. Study results showed that $58 \%$ of women from both group working and non-working were having anxiety. Almost same results were shown in another study conducted in Peshawar with 52\% anxiety ${ }^{7}$. Majority of working women were having anxiety ( $75 \%$ ) as compare to $41.25 \%$ of non - working women.

It was seen in our study that majority of the women having anxiety belonged from 21 - 35 years of age. Almost similar findings were observed in another study showing the highest peak of the psychiatric disorders was in the 16-35 years age group ${ }^{5}$. A systematic review of different papers on anxiety and depression also showed that the along with other risk factors, middle age is an important risk factor for anxiety and depression ${ }^{8}$. 
Low and middle income group was a risk factor for anxiety in our study. Almost $88 \%$ belonged from low and middle income group as compare to only $12 \%$ from high income group. If we further break up the data amongst $88 \%$ majority were from low income group i.e; $52 \%$. Similar findings were seen by other researchers as shown in a systematic review ${ }^{8}$.

Our study has shown that anxiety is more seen in the literate people as compare to illiterate people. It was seen that approximately $65.5 \%$ were either matriculate or have graduate or post graduate degrees. Our results show that educated women are also prone to develop anxiety and its related disorders. Another study show opposite results showing that low education is a risk factor for anxiety $^{8}$. However another study conducted in Karachi showed similar results as our study that significant level of anxiety could be found in educated class ${ }^{9}$.

\section{CONCLUSION:}

Frequency of anxiety among working and non-working women was $59 \%$ in Peshawar. It was more common in working women as compare to non- working women. Family system, age, low household income, marital status was the key risk factors.

\section{REFERENCES:}

1. Kausar G, Anwar D. stress in Pakistani working women. Journal of culture, society and development. 2015; 5 : 58-64

2. Institute of Medicine: Neurological, Psychiatric, and Developmental Disorders: Meeting the Challenge in the Developing World. Washington, DC , National Academy Press; 2001.

3. Niaz U, Hassan S, Husain H, Siddiqui SS: A cross-sectional study of the frequency of psychiatric morbidity in affluent urban population of Karachi. Pak J Med Sci 2004, 20:337344.

4. Ali BS, Rahbar MH, Naeem S, Tareen AL, Gul A, Samad L: Prevalence of and factors associated with anxiety and depression among women in a lower middle class semi-urban community of Karachi, Pakistan. J Pak Med Assoc 2002, 52(11):513-517.

5. Dodani, S., Zuberi, R. W. (2000). Center-based prevalence of anxiety and depression in women of the northern areas of Pakistan. Journal of Pakistan Medical Association, 50(5), 138-140.

6. Available at: http://ecommons.aku.edu/pakistan_fhs_mc_ded/19

7. Khan $\mathrm{H}$, kalia $\mathrm{S}$ etal. Prevalence and demographics of anxiety disorders: a snapshot from a community health Centre in Pakistan. Annals of general psychiatry,2007; 6 (30):

8. UK Essays. November 2013. Anxiety In Working And Non Working Women Psychology Essay. [online]. Available from: https://www.ukessays.com/essays/psychology/anxiety-inworking-and-non-working-women-psychology-essay.php?cref=1 [Accessed 14 February 2018].

9. llyas $\mathrm{M}$, Rachel J. Risk factors, prevalence, and treatment of anxiety and depressive disorders in Pakistan: systematic review. BMJ, 2004; 328 : 794

10. Khan MS, Ahmed MU, Adnan M. Frequency of generalized anxiety disorder and associated factors in an urban settlement of Karachi. JPMA, November 2013;63 (11) : 1451-1455

LICENSE: JGMDS publishes its articles under a Creative Commons Attribution Non-Commercial Share-Alike license (CC-BY-NC-SA 4.0)

COPYRIGHTS: Authors retain the rights without any restrictions to freely download, print, share and disseminate the article for any lawful purpose. It includes scholarly networks such as Research Gate, Google Scholar, LinkedIn, Academia.edu, Twitter, and other academic or professional networking sites. 